\title{
USAGES AND PRACTICES IN CONTRACTS FOR THE INTERNATIONAL SALE OF GOODS*
}

\author{
USOS Y PRÁCTICAS EN LOS \\ CONTRATOS DE COMPRAVENTA \\ INTERNACIONAL DE MERCADERÍAS
}

Jorge Oviedo-Albán**

Reception date: February 10, 2017

Acceptance date: February 28, 2017

Available online: November 30, 2017

\section{To cite this article/Para citar este artículo}

Oviedo Albán, Jorge, Usages and Practices in Contracts for the International Sale of Goods, 135 Vniversitas, 255-282 (2017). https://doi.org/10.11144/

Javeriana.vj135.upci

doi:10.11144/Javeriana.vj135.upci

* This paper is a product of the research line International Business Law of the Private Law Research Group of Universidad de La Sabana.

** Research Professor at the Faculty of Law and Political Science at Universidad de La Sabana. ORCID: 0000-0003-2174-4765. PhD and Master in Private Law, Universidad de los Andes, Santiago de Chile. Lawyer and Specialist in Commercial Law, Pontificia Universidad Javeriana, Bogotá. Contact: jorgeoa@unisabana.edu.co 


\section{ABSTRACT}

One of the most important issues in the Convention for the International Sale revolves around the ability to define the way in which it anticipates the application of other sources of law with which it is integrated. It is, therefore, necessary to establish the scope of each one of these in order to be able to establish a system of regulatory sources of contracts for the international sale of goods. In this respect, the purpose of this paper is to study the value and scope of the usages and practices as a regulatory source of contracts for the international sale of goods under the framework of the 1980 United Nations Convention. It considers both legal theory and case law interpretations.

Keywords: Usages; practices; international contracts of sales of goods 


\section{RESUMEN}

Uno de los aspectos de mayor relevancia en la Convención sobre Compraventa Internacional consiste en poder precisar la forma como la misma prevé la aplicación de otras fuentes con las que se integra. Conforme a lo anterior, es necesario establecer el alcance de cada una de ellas, para de esa manera poder establecer el sistema de fuentes reguladoras de los contratos de compraventa internacional de mercaderías. En tal contexto, este trabajo tiene por objeto estudiar el valor y alcance de los usos y prácticas como fuente reguladora de los contratos de compraventa internacional en el marco de la Convención de Naciones Unidas de 1980. Para su elaboración se han tenido en cuenta tanto la doctrina como las interpretaciones jurisprudenciales.

Palabras clave: Usos; prácticas; contratos internacionales de compraventa

\section{SUMARIO}

Introduction.- I. General Aspects.- II. Classification.- A. Business practices and conventional usages.- $B$. General usages.- III. Functions.- $A$. Interpretative functions.- $B$. Normative functions.- IV. REQUIREMENTS OF General usages.- $A$. The parties knew or ought to have known.- $B$. Widely known and regularly observed.- CONCLUSIONS.- BIBLIOGRAPHY. 


\section{INTRODUCTION}

Currently there are 86 countries that have ratified the United Nations Convention on Contracts for the International Sale of Goods signed on April $11^{\text {th }} 1980 .{ }^{1}$ In addition to the influence that it has had on the contract law harmonization process, it is possibly not necessary to draw attention to its importance as an instrument that regulates international sale contracts; however, it is convenient to do so as in Latin America it is still interesting that - to date fourteen countries from Central and South America, including several from the Caribbean, have adopted it - and there have only been a small number of decisions made that have implemented the Convention. ${ }^{2}$ For this very reason, efforts made to promote it are not in vein. These efforts emphasize the need that lawyers and judges, who are involved in these types of international operations, have to not only understand its normative text, but also the main disputes that its application has generated in different countries around the world as well as court's decisions and interpretations from legal theory.

One of the most important issues in the Convention for the International Sale revolves around the ability to define the way in which it anticipates the application of other sources of law with which it is integrated. It is, therefore, necessary to establish the scope of each one of these in order to be able to establish a system of regulatory sources of contracts for the international sale of goods. In this respect, the purpose of this paper is to study the value and scope of the usages and practices as a regulatory source of contracts for the international sale of goods under the framework of the 1980 United Nations Convention. It considers both legal theory and case law interpretations.

1 From hereon the following titles will be used: "United Nations Convention on Contracts for the International Sale of Goods"; "Convention for the International Sale"; "1980 Convention" or simply "The Convention".

2 The countries are: Argentina, Chile, Costa Rica, Uruguay, Paraguay, Brazil, Peru, Ecuador, Colombia, Guyana, French Guyana, Honduras, Mexico, Cuba, and the Dominican Republic. Information on the countries that have ratified the Convention can be found at: http://www.uncitral.org. For the importance of the Convention on what has been called the "modernization of the law of obligations" process refer to, among others: Reinhard Zimmermann, The New German Law of Obligations. Historical and Comparative Perspectives, 32-38 (Oxford University Press, Oxford, 2005). ANTONIO Manuel Morales-Moreno, La modernización del derecho de obligaciones, 146-147 (Thomson Civitas, Cizur Menor, Navarra, 2006). 
Moreover, notwithstanding the fact that this paper has been developed from a perspective that is centered on the Convention on the International Sale of Goods, it was also considered pertinent to include references to the Unidroit Principles of International Commercial Contracts. As is well known, these have established themselves as the instrument that sets out the general applicable rules to international contracts, either as an express agreement between the parties, or because the arbitrator interprets the contract as a reflection of a modern lex mercatoria. ${ }^{3}$

This paper is structured in the following way: The first section (I) details general aspects, which seek to contextualize the landscape of the regulatory sources of contracts for the international sale of goods. The second (II) refers to the classification between practices and usages, and then the third (III) subsequently identifies the interpretive and normative roles. The fourth section (IV) analyzes the specifications of contracts for the international sale of goods and issues relating to how they can be proved. Lastly, the paper ends with some final considerations and well as the bibliography.

\section{GENERAL ASPECTS}

The Convention on Contracts for the International Sale of Goods is comprised of 101 Articles that are divided into four parts: the first relates to its sphere of application and general provisions and is conformed by Articles 1-13. The second part, which is entitled Formation of the contract, is contained between Articles 14-24. The third is called Sale of goods, can be found between Articles 25-88, and includes the provisions that are relative to the buyer and seller's obligations as well as remedies for breach of contract. The forth part is the Final provisions section, which is comprised of Article 89 to 101; these refer to rules of the Convention as an international law treaty. For this reason it includes provisions relative to its adoptions and reservations.

It should also be taken into consideration that, according to what is determined in Article 4, the Convention exclusively regulates the formation of a contract of sale and the rights and obligations

3 Francesco Galgano \& Fabrizio Marrella, Diritto del commercio internazionale, 244 (CEDAM, Padova, 2004). 
of the parties. Its scope of application does not include contracts' validity, or the validity of any of its provisions or usages. Also, the effects the contract can have on the ownership of the sold goods are not included. Article 5 sets out how the Convention does not establish the responsibility of the seller for the death or physical injuries caused to an individual by the goods. The type of sales that are not included in the Convention's scope of application should also be considered; these are listed in Article 2.

The previous paragraph demonstrates that the Convention does not regulate all international contracts of sale, and it also has no rules that include every aspect that could be contained in these types of contracts. This shows, as Franco Ferrari has stated, that the Convention does not resolve every problem that could conceivably be encountered in these types of contracts, and, as such, appealing to other sources of law is necessary. ${ }^{4}$ The Convention contains provisions, such as those stated in Articles 6-9, from which a regulatory system of international contracts of sale can be constructed. ${ }^{5}$

The principle of party autonomy plays a leading role within these types of sources of law; this is recognized in Article 6 of the Convention in both a material and conflictual sense. This allows the parties to determine the content of the contract as well as to either expressly or tacitly exclude the Convention and instead use a national law. ${ }^{6}$ As such, the contractual provisions take precedent

4 Franco Ferrari, What Sources of Law for Contracts for the International Sale of Goods? Why One Has to Look Beyond the CISG, Internationales Handelsrecht, 1, 1-20, 3 (2006). Also: FranCo FERRARI, Fuentes aplicables a la compraventa internacional de mercaderías, 81-82 (MIRIAM ANDERSON \& Lorenzo Bairati, translators, Bosch, Barcelona, 2009). Franco Ferrari \& Marco Torsello, International Sales Law - CISG - in a Nutshell, 30 (West Academic Publishing, Saint Paul, Minnesota, 2014).

5 Cf. Franco Ferrari \& Marco Torsello, International Sales Law - CISG - in a Nutshell, 41. Jorge Oviedo-Albán, Los principios generales en la Convención de Naciones Unidas sobre Compraventa Internacional de Mercaderías, XLVII Boletín Mexicano de Derecho Comparado, 141, 987-1020 (2014). Available at: http://www.elsevier.es/es-revista-boletin-mexicano-derecho-comparado-77articulo-los-principios-generales-convencion-naciones-S0041863314711822. JORGE OvIEDO-ALBÁN, El carácter internacional y la interpretación uniforme de la Convención de Naciones Unidas sobre Compraventa Internacional de Mercaderías, XLV Boletín Mexicano de Derecho Comparado, 133, 253-282 (2012). Available at: http://www.scielo.org.mx/pdf/bmdc/v45n133/v45n133a9.pdf

6 On the scope of party autonomy for the international sale of goods: EsPERANZA CASTELLANOs-Ruiz, Autonomía de la voluntad y derecho uniforme en la compraventa internacional, passim (Comares, Granada, 1998). Alfonso Luis Calvo-Caravaca, Artículo 6, in La compraventa internacional de mercaderías, comentario de la Convención de Viena, 92-101 (Luis DíEz-Picazo y Ponce DE León, director and coordinator, Civitas, Madrid, 1998). Ingeborg Schwenzer \& PAscal Hachem, Article 6 , in Schlechtriem \& Schwenzer Commentary on the UN Convention on the International Sale of Goods (CISG), 101-118 (4 ${ }^{\text {th }}$ ed., Ingeborg Schwenzer, ed., Oxford University Press, Oxford, 2016). 
above the Convention's provisions (with the exception of what is written in Article 12) as well as other rules that are applicable in accordance with the Convention, except those rules that are mandatory.

Similarly, the usages and practices are of the utmost importance, and this is established in Articles 8 (3) and 9. These identify their main functions, which are referred to hereinafter. The rules in reference are the following:

Article 8 (3). In determining the intent of a party or the understanding a reasonable person would have had, due consideration is to be given to all relevant circumstances of the case including the negotiations, any practices which the parties have established between themselves, usages and any subsequent conduct of the parties.

Article 9. (1) The parties are bound by any usage to which they have agreed and by any practices which they have established between themselves.

(2) The parties are considered, unless otherwise agreed, to have impliedly made applicable to their contract or its formation a usage of which the parties knew or ought to have known and which in international trade is widely known to, and regularly observed by, parties to contracts of the type involved in the particular trade concerned. ${ }^{7}$

Additionally, Article 7.2 establishes that the issues relating to the matters governed by the Convention, but that are not expressly resolved by it, should be dealt with in accordance with the general principles in which they are based. If these principles do not exist, then they should be dealt with according to the applicable law according to the rules contained in Private International Law. ${ }^{8}$

7 The Unidroit Principles also recognize the normative value of the usages and practices in Articles 1.9 and 5.1.2. The regulations are set out as follows: "Article 1.9. (Usages and Practices) (1) The parties are bound by any usage to which they have agreed and by any practices which they have established between themselves. (2) The parties are bound by a usage that is widely known to and regularly observed in international trade by parties in the particular trade concerned except where the application of such a usage would be unreasonable."

"Article 5.1.2. (Implied obligations) Implied obligations stem from (a) the nature and purpose of the contract; (b) practices established between the parties and usages; (c) good faith and fair dealing; (d) reasonableness."

8 For lacunas in the Convention see, among others: Alfonso Luis Calvo-Caravaca, Artículo 7, in $\mathrm{La}$ compraventa internacional de mercaderías, comentario de la Convención de Viena, 102-113, 110113 (Luis Diez-Picazo y Ponce de León, director and coordinator, Civitas, Madrid, 1998). IngeborG Schwenzer \& Pascal Hachem, Article 7, in Schlechtriem \& Schwenzer Commentary on the UN Convention on the International Sale of Goods (CISG), 119-142 (4 $4^{\text {th }}$ ed., INGEBORG SCHWENZER, ed., 


\section{CLASSIFICATION}

The following classifications for usages and practices can be established for the previously mentioned regulations: ${ }^{9}$

\section{A. Business practices and conventional usages}

The Convention refers to business practices in Article 8.3, which states that they should be used in order to determine the intention of the parties. Also, Article 9.1 points out that the parties will be under obligation for any usage that they have agreed upon and for any practice that they have established with each other. ${ }^{10}$

Business practices consist of a series or sequence of prior behaviors between the related parties (that occur either simultaneously or successively), which due to the fact that they are undertaken regularly can be considered to be mandatory in future negotiations because they have turned into an accepted behavior rule. ${ }^{11}$ Several decisions made by courts have referred to these types of practices, recognizing them as mandatory. For example, the ruling made by the Basel-Stadt Civil Court (Switzerland), on December 21 1992 referred to the importance of silence, which constitutes acceptance

Oxford University Press, Oxford, 2016).

9 As Garro and Zuppi indicate, in the discussions on drafting these regulations, there was no unanimous opinion on the role that the usages should fulfill. Alejandro Miguel Garro \& Alberto Luis Zuppi, Compraventa internacional de mercaderias. La Convención de Viena de 1980, 88 ( $2^{\text {nd }}$ ed., Abeledo Perrot, Buenos Aires, 2012). The Czechoslovakian delegation, for example, proposed that custom be recognized, provided that it did not go against the Convention's regulations. Legislative History. 1980 Vienna Diplomatic Conference G. Report of the First Committee [Outline of Committee Proceedings] Document A/CONF.97/11 [Original: English $7^{\text {th }}$ April 1980]. Available at: http://www. cisg.law.pace.edu/cisg/1stcommittee/summaries10.html

10 John Honnold, Uniform Law for International Sales under the 1980 United Nations Convention, 116 ( $4^{\text {th }}$ ed., Harry M. Flechtner, edited and updated, Wolters Kluwer, Alphen aan den Rijn, 2009). María del Pilar Perales-Viscasillas, La formación del contrato en la compraventa internacional de mercaderías, 79 (Tirant lo Blanch, Valencia, 1996).

11 Peter Schlechtriem \& Petra Butler, UN Law on International Sales. The UN Convention on the International Sale of Goods, 59 (Springer, Heidelberg, 2009). BEATRIz CAMPUZANO-DíAz, La repercusión del Convenio de Viena de 11 de abril de 1980 en el ámbito de la compraventa internacional de mercaderías: estudio de su aplicación y de sus relaciones con la norma de conflicto y la Nueva Lex Mercatoria, 200 (Universidad de Sevilla, Sevilla, 2000). In terms of the concept of "practices", it is suggested to refer to: Tomás VÁzQuez-LÉPINETte, Compraventa internacional de mercaderías. Una visión jurisprudencial, 101 (Aranzadi Editorial, Elcano, Navarra, 2000). Alfonso Luis CalvoCARAVACA, Artículo 9, in La compraventa internacional de mercaderías, comentario de la Convención de Viena, 132-144, 137 (Luis DíEz-PiCAzo y PonCE DE León, director and coordinator, Civitas, Madrid, 1998). Michael G. Bridge claims that these practices do not necessarily need to have been adopted before the contract, they can be while it is being implemented. Michael G. Bridge, The International Sale of Goods, 525 ( $3^{\text {rd }}$ edition, Oxford University Press, Oxford, 2013). 
when responding to a letter of confirmation. The court found that the letters of confirmation sent by the seller and the subsequent omission of any reaction by the buyer reflected an applicable usage regarding the formation of contracts in terms of Article 9.1 of the Convention. ${ }^{12}$

Moreover, although the subject of "regularity" is a subjective question that should be specifically assessed in each case, it is generally considered to be insufficient that the parties only repeat the business practices once for a particular case, as it is necessary that they have a certain frequency and duration. ${ }^{13}$ Despite this, it is an issue that has varied in the decisions that have been taken by different courts. ${ }^{14}$ One case ruling in Germany involved a practice that had been undertaken on two previous occasions. The case was based on a contract of sale for 90 pizza boxes that was signed between a buyer (defendant) domiciled in Germany who was the proprietor of a pizzeria, and the seller, a manufacturer domiciled in Italy. The disagreement resulted from one occasion when the boxes were damaged by the hauler; on receiving the damaged boxes, the situation was reported back to the seller. On two previous occasions, faced with a similar situation, the buyer had been credited with the sum for the damages that had been incurred; however, this was not the case this particular time. The buyer then placed a new order for pizza boxes that arrived in good condition. This was

12 Switzerland, Zivilgericht Kanton Basel-Stadt, December 21 ${ }^{\text {st }} 1992$, CLOUT No. 95. Available at: http:/cisgw3.law.pace.edu/cases/921221s1.html. Also, see comments from María del PILAR PeralesVISCASIllas, Derecho comercial internacional, tomo 1, 207-208 (Pontificia Universidad Javeriana, Temis, Bogotá, 2014).

13 Martin Schmidt-Kessel, Article 9, in Schlechtriem \& Schwenzer: Commentary on the UN Convention on the International Sale of Goods (CISG), 181-196, 185 ( $4^{\text {th }}$ ed., INGEBORG SCHWENZER, ed., Oxford University Press, Oxford, 2016). Clayton P. Gillette \& Steven D. Walt, The UN Convention on Contracts for the International Sale of Goods: Theory and Practice, 121 ( $2^{\text {nd }}$ ed., Cambridge University Press, New York, 2016). Michael Joachim Bonell, Article 9. Usages and Practices, in Commentary on the International Sales Law. The 1980 Vienna Sales Convention, 103-115, 106 (Cesare Masimo Bianca \& Michael Joachim Bonell, Giuffrè, Milan, 1987). Rafael Illescas-Ortiz \& María del Pilar Perales-Viscasillas, Derecho mercantil internacional. El derecho uniforme, 125 (Editorial Centro de Estudios Ramón Areces S.A., Universidad Carlos III de Madrid, Madrid, 2003). Perales-Viscasillas cites the following as examples of these types of practices: The normal acceptance of the payment deferment or a certain discount for prompt payment; the quality of the goods to be delivered; the use of a specific means of communication for placing orders; a certain tolerance in terms of deficiencies, either quantitative or qualitative, of the goods; the acceptance of an offer without communication with the offeror (Article 18.3 CISG), etc. MARÍA DEL PILAR PeRALESVISCASILlAS, La formación del contrato en la compraventa internacional de mercaderías, 81.

14 For the judgments that have used different criteria: cfr. Clayton P. Gillette \& Steven D. Walt, The UN Convention on Contracts for the International Sale of Goods: Theory and Practice, 121. 
not paid for, as the desire was to seek some form of compensation for the damages caused by the previous order. The court rejected the defendant buyer's argument by stating that the crediting of the amount of damages on two occasions did not suffice to establish a practice between the parties under Article 9.1 of the Convention. ${ }^{15}$

Additionally, as was mentioned at the beginning of this section, Article 9.1 indicates that the parties are linked by the usages that they have agreed upon and not only the practices that have been established between them. However, to assume a normative value of the usages within the contract that are agreed upon by the parties is, in reality, the principle of party autonomy. As has been shown, this principle is in Article 6 of the convention and allows the parties to exclude it and instead use the law that they choose to govern the contract. ${ }^{16}$ In this sense, it can be understood that the exclusion can be either express or tacit, which comes from the fact that the two parties have either agreed upon a particular law to regulate the contract or agreed the determined usages that govern it. Ultimately, it is an aspect that is combined in Articles 6 and 9.1 of the Convention.

15 Germany, Amtsgericht, April 13 ${ }^{\text {th }}$ 2000, CLOUT No. 360. Available at: http://cisgw3.law.pace.edu/ cases/000413g1.html

16 In this respect, SCHMidT-KesseL states that the content of paragraph 1 of Article 9 is purely declarative as its content comes from Articles 6 and 8. Martin Schmidt-Kessel, Article 9, in Schlechtriem \& Schwenzer: Commentary on the UN Convention on the International Sale of Goods (CISG), 181196, 181-182. See also: Beatriz Campuzano-Díaz, La repercusión del Convenio de Viena de 11 de abril de 1980..., 203. Clayton P. Gillette \& Steven D. Walt, The UN Convention on Contracts for the International Sale of Goods: Theory and Practice, 120. TomÁs VÁzquez-LépinetTe, Compraventa internacional de mercaderías. Una visión jurisprudencial, 102. On the tacit exclusion of the convention and the possibility to choose the law: Jorge Oviedo-Albán, Autonomía conflictual en los contratos de compraventa internacional de mercaderías, $39-49$ (Grupo Editorial Ibáñez, Universidad de La Sabana, Bogotá, 2012). At the time, Professor Federico de CASTro had already made some provisions for the draft bill on sales, and he had pointed out that mainstream uses are not applied because of their customary value, but because the parties incorporate them into the contract. He made this statement: The parties can refer directly and expressly to certain usages or tacitly refer to them with behavior that unequivocally shows this. In both cases, the usages are not applied for their customary value, but because the parties themselves have made them part of the content of the contract. They will therefore have to consider express or implied clauses in the sales contract. Federico de CAstro y Bravo, Las leyes nacionales, la autonomía de la voluntad y los usos en el proyecto de ley uniforme sobre la venta, XI Anuario de Derecho Civil, 4, 1003-1040, 1036-1037 (1958). Available at: https://www.boe.es/publicaciones/anuarios_derecho/abrir_pdf. php?id=ANU-C-1958-40100301040_ANUARIO_DE_DERECHO_CIVIL_Las_leyes_nacionales, la_autonom\%EDa_de_la_voluntad_y_los_usos_en_el_proyecto_de_Ley_Uniforme_sobre_la venta. Also recognizing this position: María del Pilar Perales-Viscasillas, La formación del contrato en la compraventa internacional de mercaderías, 83. 
It should also be taken into consideration that the parties can establish the usages by either express or tacit agreement. ${ }^{17}$ The former can be invoked through clauses that have been inserted in the contract; for the latter, the parties' behavior can be inferred. In order to do so, it must be possible to specifically infer in each case that the intention of the contracting parties was to associate determinate usages to the contract. This can be interpreted according to the criteria established in Article 8 of the Convention. ${ }^{18}$

For example, a disagreement that arose between a German buyer (plaintiff) and an Austrian seller (defendant) was based on an addition to a basic agreement of commercial usages that governed the transactions between the parties as well as some general conditions. The seller could not demonstrate that the buyer had disclosed the basic agreement or the general conditions. The court determined that if the parties are bound by each usage or practice that have been established between them, according to Article 9.1 of the Convention, then this should be interpreted according to Article 8.1 of the Convention in order to determine that one of the parties should have known the intention of the other. ${ }^{19}$

An additional issue to which reference must be made is the possible conflict that has arisen between a contractual practice and conventional usages. There are those who support, as part of the theory, the prevalence of the latter such as Alfonso Luis Calvo-Caravaca. He argues that the business practices that are agreed upon between the contracting parties reflect their express will, govern a specific contract, and their desire to comply in the future. However, the author affirms that the contractual practices

17 Alfonso Luis Calvo-Caravaca, Artículo 9, in La compraventa internacional de mercaderías, comentario de la Convención de Viena, 132-144, 136-137. Beatriz CAMPuZano-Díaz, La repercusión del Convenio de Viena de 11 de abril de 1980..., 203. ANJA CARLSEN, Remarks on the manner in which the PECL may be used to interpret or supplement Article 9 CISG, in An International Approach to the Interpretation of the United Nations Convention on Contracts for the International Sale of Goods (1980) as Uniform Sales Law, 277-282 (John FelemEGAS, ed., Cambridge University Press, New York, 2007).

18 Alfonso Luis Calvo-Caravaca, Artículo 9, in La compraventa internacional de mercaderías, comentario de la Convención de Viena, 132-144, 137.

19 The regulation sets out the following: "1) For the purposes of this Convention statements made by and other conduct of a party are to be interpreted according to his intent where the other party knew or could not have been unaware what that intent was." Austria, Oberster Gerichtshof, February $2^{\text {nd }}$ 1995, CLOUT No. 176. Available at: http://cisgw3.law.pace.edu/cases/960206a3.html 
can be understood as the parties' tacit will that retrospectively governs general contracts. ${ }^{20}$

The opposite view of this opinion would state that the practices established between the contracting parties should prevail in this case. As such, considering that the intention can be inferred from the practices suggested by the legal relationship, it is possible to presume its preferred application in terms of the usages agreed upon. ${ }^{21}$ Also, it is not entirely correct to claim that the practices look to the past as they can arise at any time within the contractual relationship. ${ }^{22}$

\section{B. General Usages}

Article 9.2 of the Convention refers to a category that is different from the conventional usages mentioned in Article 9.1. This consists of general practices that are regularly observed in a specific field of international business. ${ }^{23}$ The same observation can be made in relation to Article 1.9.2 of the Unidroit Principles. ${ }^{24}$ In this respect, Franco Ferrari stressed that the usages to which Article 9.1 refers should not be confused with those in Article 9.2. This distinction is important whenever the former are binding and have been accepted, either expressly or tacitly, according to what was addressed in the previous section. However, the usages addressed in 9.2 are binding regardless of their eventual acceptance or incorporation in a contract, provided that the following requirements that will be referenced in the following paragraphs are fulfilled. ${ }^{25}$

20 Alfonso Luis Calvo-Caravaca, Artículo 9, in La compraventa internacional de mercaderias, comentario de la Convención de Viena, 132-144, 138.

21 Martin Schmidt-Kessel, Article 9, in Schlechtriem \& Schwenzer: Commentary on the UN Convention on the International Sale of Goods (CISG), 181-196, 186.

22 On this matter, Mariana Bernal, referring to Article 9.1 of the Convention, states that it is regarding a need for coherence in the parties' behavior due to trust that is generated between them, and also refers to Article 1.8 of the Unidroit Principles. Mariana Bernal-Fandiño, El deber de coherencia en el derecho colombiano de los contratos, 207 (Pontificia Universidad Javeriana, Bogotá, 2013).

23 A similar interpretation: Beatriz Campuzano-Díaz, La repercusión del Convenio de Viena de 11 de abril de 1980..., 202.

24 HеIKKI JoKela uses the expression usages normatifs (or normative usages) to refer to the function that recognizes customs or trade usages in Article 9.2 of the Convention. Heikкi Jokela, The Role of Usages in the Uniform Law on International Sales, 10 Scandinavian Studies in Law, 81-96 (1966). Available at: http://www.cisg.law.pace.edu/cisg/biblio/Jokela.html

25 Franco Ferrari, What Sources of Law for Contracts for the International Sale of Goods? Why One Has to Look Beyond the CISG, Internationales Handelsrecht, 1, 1-20, 17 (2006). FranCo FERRARI, Fuentes aplicables a la compraventa internacional de mercaderias, 119. Also: EsPERANZA 
It, therefore, can be asserted that these regulations refer to the general usages of international trade. This is true when they refer to usages that these parties had or should have had knowledge of and that are extensively known and regularly observed in international business in contracts of the same type of relevant trade activity. This is reflected in both Article 8.3 and 9.2. ${ }^{26}$

\section{FUNCTIONS}

The functions of the usages and practices within the context of the Convention are the following:

\section{A. Interpretative functions}

According to what is established by Article 8.3, a function can be said to be interpretative when it is stipulated that the usages and practices established between the parties as well as their most recent behavior should be consulted in order to determine the intention of one party or the understanding that a reasonable person would have had.

In the same way, Chapter 4 of the Unidroit Principles regarding the interpretation of a contract establishes that it should be interpreted according to the common intention of the contracting parties (Article 4.1). In order to do so, Article 4.3 indicates that as part of this interpretation all the circumstances should be taken into consideration, including practices (4.3.b) and usages (4.3.f) as well as other criteria.

Castellanos-Ruiz, La compraventa internacional de mercaderías, in Contratos, Tomo XVI, Los contratos internacionales (1), 381-632, 472 (MARIANO YzQuiERdo-Tolsada, dir., Thomson Reuters, Aranzadi, Cizur Menor, Navarra, 2014).

26 It is also referred to in the Unidroit Principles in Article 1.9. On Article 9, Illescas and Perales state that, "It distinguishes between conventional use and business practices, while paragraph 2 of the same provision refers to international custom". Rafael Illescas-Ortiz \& María del Pilar Perales-Viscasillas, Derecho mercantil internacional. El derecho uniforme, 125. They also state that if the differences between the institutes regulated by Article 9 are not entirely clear, it seems that the usages and practices of paragraph 1 are essentially individually effective and are only and exclusively restricted to what the contracting parties have agreed to or their normal behavior. The usage of paragraph 2 is effective per se; that is to say it is unrelated to any specific commercial operation since it can be generally applied. Rafael Illescas-Ortiz \& María del Pilar PeralesVISCASILlas, Derecho mercantil internacional. El derecho uniforme, 126. 


\section{B. Normative functions}

Secondly, a normative function is recognized in Article 9 of the Convention as well as in Article 1.9 of the Unidroit Principles as it is established that the parties are bound by any use that they have agreed upon and any practice that has been established between them. It should also be considered that unless otherwise agreed upon, the parties have made a usage that is tacitly applicable to the contract or to its formation, if it fulfills the requisites that are referred to later on in this paper.

The interpretation, which is seemingly a general one, consists in asserting that the usages and practices are applicable more frequently than the provisions of the Convention and replaces the free will of the parties as they can exclude the usages and practices they wish. ${ }^{27}$

27 Jorge AdAme-Goddard, El contrato de compraventa internacional, 79 (McGraw-Hill, México, 1994). Alfonso Luis Calvo-Caravaca, Artículo 9, in La compraventa internacional de mercaderías, comentario de la Convención de Viena, 132-144, 144. Alejandro Miguel Garro \& Alberto Luis ZuPPI, Compraventa internacional de mercaderías. La Convención de Viena de 1980, 88-89. MARTIN Schmidt-Kessel, Article 9, in Schlechtriem \& Schwenzer: Commentary on the UN Convention on the International Sale of Goods (CISG), 181-196, 186. Refer to ICC, Court of Arbitration of the International Chamber of Commerce, ICC Arbitration Case 8611/HV/JK, January $23^{\text {rd }} 1997$. Available at: http://cisgw3.law.pace.edu/cases/978611i1.html. In this case, resulting from a lawsuit that was filed by the seller as a result of the buyer not paying for some of the deliveries that were agreed upon. The buyer counterclaimed by arguing for compensation for damages that were the result of breach of contract as well as a lack of conformity for particular products and replacement parts not being delivered. The court considered that the buyer had not presented sufficient evidence of the products' lack of conformity and had also not opportunely made the seller aware of the unsatisfactory products according to Article 39 of the Convention. Thus, as such, the buyer was made to pay for the deliveries as well as the interests that Article 78 refers to. These were calculated according to German law considering that the German legislation was applicable to the contract and at the same time the country's law established that the sum should be paid in its national currency. However, it was accepted that the delivery of replacement parts was considered an established practice between the parties according to Article 9 of the Convention, and, as such, the buyer had the right to give compensation for part of the seller's claim, including the loss of profits. Beatriz CAMPUZANo-Díaz provides commentary on this ruling El Convenio de Viena de 11 de abril de 1980 como núcleo en la regulación de la compraventa internacional de mercaderías (comentario a propósito de la Sentencia arbitral de la CCI $n^{o}$. 8611/HV/JK de 23 de enero de 1997), 9 Derecho de los Negocios, 99, 15-28 (1998). The author notes that the Convention is not a regulation of the first order and the usages prevail it. On this point, also see: Anselmo Martinez-Cañellas, La prescripción de las acciones de la CISG derivadas de la falta de conformidad de las cosas entregadas, in Rudolf Meyer zum Abschied: Dialog Deutschland-Schweiz VII, 165-183, 176, note 31 (Michael R. Will, ed., Faculté de droit, Université de Genève, Genève, 1999). Also see, Austria, Oberster Gerichtshof, October $15^{\text {th }}$ de 1998, CLOUT No. 240. Available at: http://cisgw3.law.pace.edu/cases/981015a3.html. The case was about a dispute that arose between a sales company domiciled in Austria (plaintiff) and a company that was domiciled in Italy (defendant); both companies are in the wood business. The seller sued for the payment of outstanding bills and interest, and despite the buyer having made some payments, no reference had been made to one particular delivery or specific bills. The Supreme 
This means that within the context of the Convention the contra legem value of the usages is recognized, given that if there is a conflict between them and the text in the Convention, the first should take precedence. ${ }^{28}$ However, it is necessary to mention that, as stated by Luis Fernández de la Gándara and Alfonso Luis Calvo-Caravaca, the efficiency and validity of the said usages are limited by the regulations of international public order, in this case, the internationally mandatory national law would have taken precedence if the Vienna Convention was not in force. ${ }^{29}$

Additionally, it could be assumed that as part of the normative function that complies with the usages, a complimentary function of the Convention is also included in such a way that these usages can be taken into consideration in order to fill any gaps in the Convention. As such, when noting the normative function of the usages, Miguel Checa-Martínez's legal theory states that they will be, therefore, applicable to the integration of the contract. It also states that the Convention has a supplementary efficiency: this can be observed in the cases in which a usage of commerce can

Court considered that the Convention was applicable to the case, and it established that the Court of First Instance should review if Article 9.2 of the Convention's requisites had been fulfilled in terms of adhering to the usages especially in terms of usages that were extensively understood and that were commonly adhered to in commerce. This could resolve the existing differences between the notification period of the lack of conformity between the usages and the Convention's regulations

28 On this topic see Alfonso Luis Calvo-Caravaca, Artículo 9, in La compraventa internacional de mercaderías, comentario de la Convención de Viena, 132-144, 141. It has been recognized as such in case law, for example see the following ruling: Argentina, National Commercial Court of First Instance, No. 10, October $6^{\text {th }} 1994$, Bermatex v. Valentin Rius. Available at: http://cisgw3.law.pace. edu/cases/941006al.html. The ruling expressly stated that "[The Convention]... does not state any interest rate, it does impose the application of international business practices, to which a higher hierarchy is ascribed over the very provisions of the Convention (Article 9)." The case involves two sellers domiciled in Spain and the Czech Republic and a buyer domiciled in Argentina. These were reviewed under a credit framework in the buyer company's meeting of creditors. In terms of the transaction that was carried out between the seller from the Czech Republic and the Argentinean company, it was established that the Convention did not set interest rates, and such the usages in international trade should apply in accordance with Article 9.

29 Luis Fernández de la Gándara \& Alfonso Luis Calvo-Caravaca, Derecho mercantil internacional, $599\left(2^{\text {nd }}\right.$ ed., Tecnos, Madrid, 1995). It is also necessary to mention that within the official Comments to the articles of the Unidroit Principles it is written that the usages take precedence over the provisions. "Both courses of dealing and usages, once they are applicable in a given case, prevail over conflicting provisions contained in the Principles. The reason for this is that they bind the parties as implied terms of the contract as a whole or of single statements or other conduct on the part of the one of the parties. As such, they are superseded by any express term stipulated by the parties but, in the same way as the latter, they prevail over the Principles, the only exception being those provisions which are specifically declared to be of a mandatory character." Unidroit, International Institute for the Unification of Private Law, Unidroit Principles of International Commercial Contracts 2010, 28 (Rome, 2010). Available at: http://www.unidroit.org/english/principles/contracts/ principles2010/integralversionprinciples2010-e.pdf 
resolve a gap or a lacuna that can be found in both the contract and the Convention. ${ }^{30}$ This can be illustrated by a case regarding the obligations that come with unpaid money. Article 78 of the Convention establishes that the creditor has the right to collect any corresponding interest. Cases can be found in case law in which it has been decided that the interest rate should be fixed according to the usages of international activity. ${ }^{31}$

\title{
IV. REQUIREMENTS OF GENERAL USAGES
}

\author{
As several authors have highlighted, the validity of commercial \\ usages (or general usages as they have been called for the purposes \\ of this article), do not depend on the agreement made between the \\ parties in either express or tacit agreements but on their objective \\ value. ${ }^{32}$ The same can be said in accordance with what is stated in \\ Number 2 of Article 1.9 of the Unidroit Principles. \\ The following are the requisites that Article 9 (2) of the Conven- \\ tion indicates so as the trade usages have a value.
}

30 To develop this idea the author includes that, "there are many ways in which the Vienna Convention can be complimented by trade usages (praeter legem usages). As such, when sharing the costs relating to customs, the disclosure rules regarding the sending of goods and the approximate date of arrival, the methods and costs of examining and verifying the goods, the suitability of the goods for normal usage or the specific usage for which they have been purchased, the way to or formalities on communicating any effects of conformity when the goods are examined, the responsibility to send any meaningful ownership titles to the buyer so that the goods can be collected, measures should be taken to comply with the mitigation of damage principle that corresponds to the seller and buyer, etc." Miguel Checa-Martínez, Los usos del comercio en perspectiva comparada y transnacional, in Derecho contractual comparado. Una perspectiva europea y transnacional, 267-310, 282 (2 ${ }^{\text {nd }}$ ed., Sixto SÁnchez-Lorenzo, editor, Civitas, Thomson Reuters, Cizur Menor, Navarra, 2013). Also, refer to JosEPH LOOKOFSKy, Convention on Contracts for the International Sale of Goods (CISG), 61 (Wolters Kluwer, Alphen aan den Rijn, 2012). Available at: http://www.cisg.law.pace.edu/cisg/biblio/ lookofsky.html. Another aspect that should be considered in order to recognize the complimentary value of the usages is assuming that their normative value, according to Article 7.2, is a principle in which the Convention is based. As such, the regulation in Article 7.2, according to which the provisions relating to matters governed by it are not expressly resolved in the article, will be settled in accordance with the principles in which they are based. Accordingly, see AnSELMo MARTínezCAÑEllas, La interpretación y la integración de la Convención de Viena sobre la compraventa internacional de mercaderías, de 11 de abril de 1980, 326 (Comares, Granada, 2004).

31 Accordingly, see: Argentina, National Commercial Court of First Instance in Buenos Aires, $6^{\text {th }}$ October 1994, cit., Argentina, National Commercial Court of First Instance No. 10, October $23^{\text {rd }}$ 1991, Aguila Refractarios S.C. s/ Conc. Preventivo. Available at: http:/www.unilex.info

32 Alfonso Luis Calvo-Caravaca, Artículo 9, in La compraventa internacional de mercaderías, comentario de la Convención de Viena, 132-144, 138. Franco Ferrari, What Sources of Law for Contracts for the International Sale of Goods? Why One Has to Look Beyond the CISG, Internationales Handelsrecht, 1, 1-20, 17 (2006). Franco FerRARI, Fuentes aplicables a la compraventa internacional de mercaderías, 117 (Miriam Anderson \& LoRenzo Bairati, translators, Bosch, Barcelona, 2009). 


\section{A. The parties knew or ought to have known}

It is not necessary that the parties actually have a knowledge of these usages, as their enforceability comes from their generality, which clearly differentiates them from specific or conventional usages. In many fields of international trade sale and purchases, such as maritime, insurance, financial transactions, etc., practices or usages are accepted that apply to these businesses despite businessmen's unfamiliarity with them or their inclusion in contracts. ${ }^{33}$

As has been indicated in legal theory, Article 9 of the Convention is based on two theories that reflect the role of the usages in trade contracts. ${ }^{34}$ The first is known as the "subjective theory" and it details that the usages are only applicable when the parties have a knowledge of them. As such, if the parties do not know the usages, they are not enforceable. Conversely, according to the "objective theory", if the parties are not aware of the usages, they can still be enforced. As such, Article 9.2 of the Convention is a compromise between the two theories as the usages that the parties knew of ought to have known take precedence. ${ }^{35}$

It has been argued that the requirement that the parties "should have known" demands a necessary diligence on their behalf. When engaging in international business, they should have a knowledge of the usages or, failing this, find out about them. ${ }^{36}$ However, the view could be taken, as has already been written in the legal

33 United States, U.S. District Court for the Southern District of New York [Federal Court of $1^{\text {st }}$ instance], May 10 th 2002, Geneva Pharmaceuticals Tech. Corp. v. Barr Labs. Inc. [98 CIV 861 (RWS) and 99 Civ 3607 (RWS)] DC (Southern Dist. NY). Available at: http://cisgw3.law.pace.edu/ cases/020510u1.html. In this case the court established that the parties or industry's usages and practices are automatically incorporated in a contract that is governed by the Convention unless they have been expressly excluded by the parties, according to Article 9 .

34 Cfr. Alejandro Miguel Garro \& Alberto Luis Zuppi, Compraventa internacional de mercaderías. La Convención de Viena de 1980, 89. ANJA CARLSEN, Remarks on the manner in which the PECL may be used to interpret or supplement Article 9 CISG, in An International Approach to the Interpretation of the United Nations Convention on Contracts for the International Sale of Goods (1980) as Uniform Sales Law, 277-282, 278-279. Also, HeiкKi Jokela, The Role of Usages in the Uniform Law on International Sales, 10 Scandinavian Studies in Law, 81-96 (1966).

35 As Garro, Zuppi and Carlsen claim, during discussions socialist countries and developing countries refused an objective or unimpeded application of the usages when they consider that these originate in industrialized countries. Alejandro Miguel Garro \& Alberto Luis Zuppi, Compraventa internacional de mercaderías. La Convención de Viena de 1980, 88. ANJA CARLSEN, Remarks on the manner in which the PECL may be used to interpret or supplement Article 9 CISG, in An International Approach to the Interpretation of the United Nations Convention on Contracts for the International Sale of Goods (1980) as Uniform Sales Law, 277-282.

36 Beatriz Campuzano-Díaz, La repercusión del Convenio de Viena de 11 de abril de 1980..., 206. 
theory, that this requirement should be specifically evaluated in several particular cases, particularly in situations in which certain operators (either sellers or buyers) are domiciled or operate in developing countries or regions that are not highly industrialized in which there is either little or no knowledge of certain uses. ${ }^{37} \mathrm{On}$ this point, Jorge Adame-Goddard points out that Article 8.2 of the Convention should be interpreted in such a way that it should be considered what the same type of reasonable person should know. ${ }^{38}$

The broadest understanding of the wording of Article 1.9 of the Unidroit Principles should be highlighted. This states that usages must be widely known and regularly observed in international trade by the parties that are involved in the trade activity in question. The objective parameter to determine the existence of usages will be that which is regularly observed by those involved in the trade activity in question.

It is worthwhile mentioning that several courts have recognized the normative value of usages of international trade within the context of operations governed by the Convention, and have also understood that they are embodied in several instruments such as the Unidroit Principles and the Incoterms. An example is the decision made by the United States Federal Appellate Court $\left[5^{\text {th }}\right.$ Circuit], which considered that the Convention included Incoterms in Article 9.2. The fact that they are recognized in international trade means that they are incorporated through Article 9.2. ${ }^{39}$ Similarly,

37 Cfr. Bernard Audit, La compraventa internacional de mercaderías: Convención de las Naciones Unidas del 11 de abril de 1980 (ratificada por la ley 22.765), 56 (RiCARDO DE ZAVALía, translator, Zavalía Editor, Buenos Aires, 1994). Calvo Caravaca, ob. cit., p. 142. Beatriz Campuzano-Díaz, La repercusión del Convenio de Viena de 11 de abril de 1980 ..., 207-208. María del Pilar PeralesVISCASILlas, La formación del contrato en la compraventa internacional de mercaderías, 85. MigueL Checa-Martínez, Los usos del comercio en perspectiva comparada y transnacional, in Derecho contractual comparado. Una perspectiva europea y transnacional, 267-310, 281.

38 Jorge AdAme-Goddard, El contrato de compraventa internacional, 82 (McGraw-Hill, México, 1994).

39 United States, U.S. Court of Appeals ( $5^{\text {th }}$ Circuit) [Federal Appellate Court], June $11^{\text {th }} 2003$, BP Oil International, Ltd., and BP Exploration \& Oil, Inc., v. Empresa Estatal de Petróleos de Ecuador et al., CCA (5 ${ }^{\text {th }}$ Circuit), [02-20166]. Available at: http://cisgw3.law.pace.edu/cases/030611u1.html. Also, see the following ruling: United States, U.S. District Court for the Southern District of New York [Federal Court of $1^{\text {st }}$ instance], March $26^{\text {th }} 2002$, St. Paul Guardian Insurance Company et al. v. Neuromed Medical Systems \& Support et al. DC (Southern Dist., NY) [00 Civ. 934 (SHS)]. Available at: http://cisgw3.law.pace.edu/cases/020326u1.html. The court concluded that the risk of loss passed to the buyer upon delivery to the port of shipment by virtue of the CIF delivery term. The court found that the International Chamber of Commerce's 1990 CIF incoterm governed by virtue of article 9(2) CISG. The court also noted that German courts apply the incoterm as a commercial practice with the force of law. 
an arbitration case decide upon by a Russian Court of Arbitration recognized the Unidroit Principles as usages incorporated into the contract in accordance with Article 9.2 of the Convention. ${ }^{40}$

\section{B. Widely known and regularly observed}

In terms of the widely known requirement, this should in principle be understood in the sense that the usages should be international due to the fact that they refer to operations of that nature. In other words, this regards the usages applicable to international trade operations and not usages that are exclusively in national operations. ${ }^{41}$

Although this could lead to the opinion that they should be globally known, both the legal theory and the case law have affirmed that it is unnecessary for them to be known in every commercial area. However, they should be known in regional or local operations provided that they arise from international trade operations or they are directly related to them. This excludes the application of developed usages or ones that come from transactions in domestic activity as they are deemed to be irrelevant to the purposes of international trade. ${ }^{42}$

40 ICC, Tribunal of International Commercial Arbitration at the Russian Federation Chamber of Commerce and Industry, ICC Arbitration Case 229/1996, June $5^{\text {th }} 1997$. Available at: http://cisgw3. law.pace.edu/cases/970605r1.html. Also, ICC, Court of Arbitration of the International Chamber of Commerce, ICC Arbitration Case, 9333, 1998. Available at: http://cisgw3.law.pace.edu/ cases/989333il.html

41 Alfonso luis Calvo-Caravaca, Artículo 9, in La compraventa internacional de mercaderías, comentario de la Convención de Viena, 132-144, 142.

42 This position is generalized in the legal theory. In this respect, see BERNARD AUDIT, La compraventa internacional de mercaderias: Convención de las Naciones Unidas del 11 de abril de 1980 (ratificada por la ley 22.765), 56-57. JoHn HonNOLD, Uniform Law for International Sales under the 1980 United Nations Convention, 172. Alfonso Luis Calvo-Caravaca, Artículo 9, in La compraventa internacional de mercaderías, comentario de la Convención de Viena, 132-144, 142. BEATRIz CAMPUZANO-DíAz, La repercusión del Convenio de Viena de 11 de abril de 1980..., 207. LuIS FERnÁNDEZ De la Gándara \& Alfonso Luis Calvo-Caravaca, Derecho mercantil internacional, 186 (2 ${ }^{\text {nd }}$ ed., Tecnos, Madrid, 1995). Franco Ferrari, Fuentes aplicables a la compraventa internacional de mercaderías, 120 (Miriam Anderson \& Lorenzo Bairati, translators, Bosch, Barcelona, 2009). Franco Ferrari, Trade Usage and Practices Established between the Parties under the CISG, 5 International Business Law Journal, 571-580, 574 (2003).

Franco Ferrari, The Relationship between International Uniform Contract Law Conventions, 22 Journal of Law and Commerce, 57-75, 74 (2003). Available at: https://www.cisg.law.pace.edu/cisg/ biblio/ferrari7.html. Franco Ferrari \& Marco Torsello, International Sales Law - CISG - in a Nutshell, 42. Ralph Folsom, Michael Wallace Gordon, John A. Spanogle \& Michael P. van Alstine, International Business Transactions in a Nutshell, 62 ( $9^{\text {th }}$ ed., West Group, Saint Paul, Minnesota, 2012). Martin Schmidt-Kessel, Article 9, in Schlechtriem \& Schwenzer: Commentary on the UN Convention on the International Sale of Goods (CISG), 181-196, 190-191. MARÍA DEL PILAR PERALESVISCASILLAS, La formación del contrato en la compraventa internacional de mercaderías, 84 . Also 
As such, local usage could be applicable in some circumstances, (this is insisted upon) when it is directly related to an international trade transaction. ${ }^{43}$

The ruling on November $9^{\text {th }} 1995$ by the Appellate Court Graz, Austria: the Court of Appeal held that article 9(2) CISG, save a limited number of exceptions, could not be interpreted as barring the application of national or local usage in interpreting a contract even though no mention of such usage was made in the contract itself. Accordingly, a seller who has been engaging in business in a county for many years and has repeatedly concluded contracts of the type involved in the particular trade concerned is obliged to take national usage into consideration.

...held that article 9(2) CISG, save a limited number of exceptions, could not be interpreted as barring the application of national or local usage in interpreting a contract even though no mention of such usage was made in the contract itself. Accordingly, a seller who has been engaging in business in a county for many years and has repeatedly concluded contracts of the type involved in the particular trade concerned is obliged to take national usage into consideration. ${ }^{44}$

A case was brought before the Austrian courts that involved a German seller (plaintiff) and an Austrian buyer (defendant) who entered into contract for the sale of wood. The seller maintained that the regional commercial usages (Tegernseer Gebräuche) applied to the contract of sale. The Court of First Instance's ruling, which was then upheld by the Court of Appeal and the Supreme Court, assumed that these usages were customary in contracts of sale for wood between the German and Austrian parties as they are appli-

see, Rafael Illescas-Ortiz \& Pilar Perales-Viscasillas, Derecho mercantil internacional. El derecho uniforme, 128.

43 Esperanza Castellanos-Ruiz, La compraventa internacional de mercaderías, in Contratos, Tomo XVI, Los contratos internacionales (1), 381-632, 475. STEFan Vogenauer, Article 1.9, in Commentary on the Unidroit Principles of International Commercial Contracts (PICC), 192-201, 197 (STEFAN Vogenauer \& Jan Kleinheisterkamp, eds., Oxford University Press, Oxford, 2009). The author says: "The usage must concern the international trade in the particular trade sector. This excludes purely local, regional, or national usages. There are two reasons for this. First, many domestic usages are not particularly well adapted to the needs of international transactions. Second, no party should be bound by a usage that it cannot reasonably be expected to be aware of. Whilst a trader engaging in international commercial transactions can be expected to be familiar with the international trade usages in its trade sector, it cannot normally be expected to be aware of particular usages that are limited to a geographical area that is foreign to it". Stefan Vogenauer, Article 1.9, in Commentary on the Unidroit Principles of International Commercial Contracts (PICC), 192-201, 197.

44 Austria, Oberlandesgericht Graz, November $9^{\text {th }} 1995$, CLOUT No. 175, in the CISG Pace database, http://cisgw3.law.pace.edu/cases/951109a3.html. The following also comments on this case: ТомÁs VÁzQuez-LÉPINETTE, Compraventa internacional de mercaderías. Una visión jurisprudencial, 103. 
cable according to Article 9.2 of the Convention. Additionally, the Supreme Court assumed that while Article 9.2 of the Convention implied that the parties are bound by the usages of international trade, the usages agreed upon by express or implicit agreement under Article 9.1 do not necessarily have to be. The Supreme Court also commented about Article 9.2's requirement being widely recognized and regularly observed, and assumed that this is true when the usages are recognized by the majority of people who undertake commercial activities in the same field..$^{45}$

Additionally, it should be considered that requirement of being widely known and regularly observed applies to both parties. As such, according to the OLG Frankfurt ruling of $5^{\text {th }}$ July 1995, regarding a contract entered into between a seller domiciled in France and a buyer domiciled in Germany, it was debated if a usage recognized in Germany of verifying a contract with a "letter of confirmation", which according to such usage was understood in the absence of a response as acceptance, could or could not be understood as an international usage for the purposes of the Convention. The court assumed that the usage could not be understood as such as this method was not used in France, only in Germany; only trade usages that are known in both the offering country as well as the offeree country must be taken into account. Also, the legal effects of this trade usage must be understood by both parties. ${ }^{46}$

In order to better understand the requirement that the widely known usage is mandatory unless the application of the usage is not reasonable ${ }^{47}$ it is useful to refer to the explanation and illustration that is included in the official text of Article 1.9 of the Unidroit Principles on the matter.

"A usage may be regularly observed by the generality of business people in a particular trade sector but its application in a given case may nevertheless be unreasonable. Reasons for this may be found

45 Austria, Oberster Gerichtshof, 10 Ob 344/99g, March 21 $1^{\text {st }} 2000$, CLOUT No. 425. Available at: http://cisgw3.law.pace.edu/cases/000321a3.html

46 Germany, Oberlandesgericht Frankfurt, July $5^{\text {th }} 1995$, CLOUT No. 276. Available at: http://cisgw3. law.pace.edu/cases/950705g1.html. For an analysis of this ruling, see María del Pilar PeralesViscasillas, Derecho comercial internacional, tomo 1, 210.

47 During the conferences in which the drafting of the Vienna Convention was debated, the possibility was discussed of including the term reasonability for the usages; however, finally it was not included. Patrick X. Bout, Trade Usages: Article 9 of the Convention on Contracts for the International Sale of Goods 
in the particular conditions in which one or both parties operate and/or the atypical nature of the transaction. In such cases the usage will not be applied.

\section{Illustration}

5. A usage exists in a commodity trade sector according to which the purchaser may not rely on defects in the goods if they are not duly certified by an internationally recognized inspection agency. When A, a buyer, takes over the goods at the port of destination, the only internationally recognised inspection agency operating in that port is on strike and to call another from the nearest port would be excessively costly. The application of the usage in this case would be unreasonable and A may rely on the defects it has discovered even though they have not been certified by an internationally recognised inspection agency. ${ }^{48 "}$

The Convention does not contain any provision relating to proving usages and practices. In accordance with Article 7 of the Convention, this matter should be resolved by the applicable national regulations according to International Private Law, and it can refer to rulings that have recognized them as such, to the opinions of the local Chamber of Commerce, or facts collected by specialized institutions. ${ }^{49}$

48 Unidroit, International Institute for the Unification of Private Law, Unidroit Principles of International Commercial Contracts 2010, 27.

49 Jorge AdAme-Goddard, El contrato de compraventa internacional, 84 (McGraw-Hill, México, 1994). According to Calvo-Caravaca there are three hypothesis in which the need to prove the existence and content of the usages and practices could be envisaged Firstly, apart from anything contentious: in this case it is not dangerous to risk that the burden of proof falls upon the party who calls upon the use. Secondly, throughout the procedure, in this scenario the regit processum principle, which is conducted with lex fori, in accordance with which the application must be determined ex officio or at the request of one of the parties and could eventually distinguish between the object and the burden of proof, the admissibility of evidence (agreements between the parties, judgments, or resolutions from Chambers of Commerce), the probative force of the evidence and the arbitration proceeding. Thirdly, in an arbitration case, under some laws and rules of arbitration, it is established that the arbitrators should take into consideration the prevailing usages in the sectors of economic activity of which they have knowledge. Alfonso Luis Calvo-Caravaca, Artículo 9, in La compraventa internacional de mercaderías, comentario de la Convención de Viena, 132-144, 143-144. 


\section{CONCLUSIONS}

The following points are the summaries of the main conclusions that have been drawn in this paper.

1. The Convention on the International Sale recognizes a non-hierarchal and open order of legal sources that allows for the parties, interpreters, and judges or referees to be creative in their decision-making process.

2. The Convention on the International Sale recognizes the main value of contractual practices and usages as sources that generate rules of conduct.

3. International jurisprudence has recognized the normative value of usages as long as it fulfills the requirements of being publicly known and based on repetition. Additionally, there are rulings based on which the legal theory has established that in contracts for the international sale of goods that are governed by the United Nations Convention of 1980, the usages are accepted contra legem. As such, if there is a conflict between the customary rule and the Convention's regulations, the first will take precedence.

4. The usages within the context of the Convention and other instruments such as the Unidroit Principles do not need to be universal. Their international nature can be attributed to a practice that despite only belonging to one particular place is such because it derives from international trade transactions that are undertaken in that particular place. 


\section{BIBLIOGRAPHY}

\section{Books}

Adame-Goddard, Jorge, El contrato de compraventa internacional (McGraw-Hill, México, 1994).

Audit, Bernard, La compraventa internacional de mercaderías: Convención de las Naciones Unidas del 11 de abril de 1980 (ratificada por la ley 22.765) (RICARDO DE Zavalía, translator, Zavalía Editor, Buenos Aires, 1994).

Bernal-Fandiño, Mariana, El deber de coherencia en el derecho colombiano de los contratos (Pontificia Universidad Javeriana, Bogotá, 2013).

Bianca, Cesare Masimo \& Bonell, Michael Joachim, Commentary on the International Sales Law. The 1980 Vienna Sales Convention (Giuffrè, Milan, 1987).

Bout, Patrick X., Trade Usages: Article 9 of the Convention on Contracts for the International Sale of Goods. Available at: http://www.cisg.law.pace.edu/cisg/ biblio/bout.html

Bridge, Michael G., The International Sale of Goods (3 $3^{\text {rd }}$ edition, Oxford University Press, Oxford, 2013).

Campuzano-Díaz, Beatriz, La repercusión del Convenio de Viena de 11 de abril de 1980 en el ámbito de la compraventa internacional de mercaderías: estudio de su aplicación y de sus relaciones con la norma de conflicto y la Nueva Lex Mercatoria (Universidad de Sevilla, Sevilla, 2000).

Castellanos-Ruiz, Esperanza, Autonomía de la voluntad y derecho uniforme en la compraventa internacional (Comares, Granada, 1998).

Díez-Picazo y Ponce de León, Luis, director, coordinator, La compraventa internacional de mercaderías. Comentario de la Convención de Viena (Civitas, Madrid, 1998).

Fernández de la Gándara, Luis \& Calvo-Caravaca, Alfonso Luis, Derecho mercantil internacional (2nd ed., Tecnos, Madrid, 1995).

Ferrari, Franco, Fuentes aplicables a la compraventa internacional de mercaderías (Miriam Anderson \& Lorenzo Bairati, translators, Bosch, Barcelona, 2009).

Ferrari, Franco \& Torsello, Marco, International Sales Law - CISG - in a Nutshell (West Academic Publishing, Saint Paul, Minnesota, 2014).

Folsom, Ralph; Gordon, Michael Wallace; Spanogle, John A. \& Alstine, Michael P. vAN, International Business Transactions in a Nutshell ( $9^{\text {th }}$ ed., West Group, Saint Paul, Minnesota, 2012).

Galgano, Francesco \& Marrella, Fabrizio, Diritto del commercio internazionale (CEDAM, Padova, 2004).

Garro, Alejandro Miguel \& Zuppi, Alberto Luis, Compraventa internacional de mercaderías. La Convención de Viena de 1980 ( $2^{\text {nd }}$ ed., Abeledo Perrot, Buenos Aires, 2012).

Gillette, Clayton P. \& Walt, Steven D., The UN Convention on Contracts for the International Sale of Goods: Theory and Practice ( $2^{\text {nd }}$ ed., Cambridge University 
Press, New York, 2016).

Honnold, John, Uniform Law for International Sales under the 1980 United Nations Convention (4th ed., HARry M. Flechtner, edited and updated, Wolters Kluwer, Alphen aan den Rijn, 2009).

Illescas-Ortiz, Rafael \& Perales-Viscasillas, María del Pilar, Derecho mercantil internacional. El derecho uniforme (Editorial Centro de Estudios Ramón Areces S.A., Universidad Carlos III de Madrid, Madrid, 2003).

Lookofsky, Joseph, Convention on Contracts for the International Sale of Goods (CISG) (Wolters Kluwer, Alphen aan den Rijn, 2012). Available at: http://www.cisg.law. pace.edu/cisg/biblio/lookofsky.html

Martínez-Cañellas, Anselmo, La interpretación y la integración de la Convención de Viena sobre la compraventa internacional de mercaderías, de 11 de abril de 1980 (Comares, Granada, 2004).

Morales-Moreno, Antonio Manuel, La modernización del derecho de obligaciones (Thomson Civitas, Cizur Menor, Navarra, 2006).

Oviedo-Albán, Jorge, Autonomía conflictual en los contratos de compraventa internacional de mercaderías (Grupo Editorial Ibáñez, Universidad de La Sabana, Bogotá, 2012).

Perales-Viscasillas, María del Pilar, Derecho comercial internacional, tomo 1 (Pontificia Universidad Javeriana, Temis, Bogotá, 2014).

Perales-Viscasillas, María del Pilar, La formación del contrato en la compraventa internacional de mercaderías (Tirant lo Blanch, Valencia, 1996).

Schlechtriem, Peter \& Butler, Petra, UN Law on International Sales. The UN Convention on the International Sale of Goods (Springer, Heidelberg, 2009).

VÁzquez-Lépinette, Tomás, Compraventa internacional de mercaderías. Una visión jurisprudencial (Aranzadi Editorial, Elcano, Navarra, 2000).

Zimmermann, Reinhard, The New German Law of Obligations. Historical and Comparative Perspectives (Oxford University Press, Oxford, 2005).

\section{Contribution in collective books}

Bonell, Michael Joachim, Article 9. Usages and Practices, in Commentary on the International Sales Law. The 1980 Vienna Sales Convention, 103-115 (CESARE Masimo Bianca \& Michael Joachim Bonell, Giuffrè, Milan, 1987).

Calvo-Caravaca, Alfonso Luis, Artículo 6, in La compraventa internacional de mercaderías, comentario de la Convención de Viena, 92-101 (Luis DíEz-PICAzo y PonCe de León, director and coordinator, Civitas, Madrid, 1998).

Calvo-Caravaca, Alfonso Luis, Artículo 7, in La compraventa internacional de mercaderías, comentario de la Convención de Viena, 102-113 (Luis DíEz-PicAzo y PONCE DE LEÓN, director and coordinator, Civitas, Madrid, 1998).

Calvo-Caravaca, Alfonso Luis, Artículo 9, in La compraventa internacional de mercaderías, comentario de la Convención de Viena, 132-144 (Luis Díez-Picazo 
y PonCE DE LeÓn, director and coordinator, Civitas, Madrid, 1998).

CARLSEn, AnJa, Remarks on the manner in which the PECL may be used to interpret or supplement Article 9 CISG, in An International Approach to the Interpretation of the United Nations Convention on Contracts for the International Sale of Goods (1980) as Uniform Sales Law, 277-282 (John Felemegas, ed., Cambridge University Press, New York, 2007).

Castellanos-Ruiz, Esperanza, La compraventa internacional de mercaderías, in Contratos, Tomo XVI, Los contratos internacionales (1), 381-632 (MARIANo Yzquierdo-Tolsada, dir., Thomson Reuters, Aranzadi, Cizur Menor, Navarra, 2014).

Checa-Martínez, Miguel, Los usos del comercio en perspectiva comparada y transnacional, in Derecho contractual comparado. Una perspectiva europea y transnacional, 267-310 ( $2^{\text {nd }}$ ed., Sixto SÁncheZ-Lorenzo, editor, Civitas, Thomson Reuters, Cizur Menor, Navarra, 2013).

Martínez-Cañellas, Anselmo, La prescripción de las acciones de la CISG derivadas de la falta de conformidad de las cosas entregadas, in Rudolf Meyer zum Abschied: Dialog Deutschland-Schweiz VII, 165-183 (Michael R. WiLl, ed., Faculté de droit, Université de Genève, Genève, 1999).

Schmidt-Kessel, Martin, Article 9, in Schlechtriem \& Schwenzer: Commentary on the UN Convention on the International Sale of Goods (CISG), 181-196 ( $4^{\text {th }}$ ed., INGEBORG Schwenzer, ed., Oxford University Press, Oxford, 2016).

Schwenzer, Ingeborg \& Hachem, Pascal, Article 6, in Schlechtriem \& Schwenzer Commentary on the UN Convention on the International Sale of Goods (CISG), 101-118 ( $4^{\text {th }}$ ed., Ingeborg SChwenZer, ed., Oxford University Press, Oxford, 2016).

Schwenzer, Ingeborg \& Hachem, Pascal, Article 7, in Schlechtriem \& Schwenzer Commentary on the UN Convention on the International Sale of Goods (CISG), 119-142 (4 ${ }^{\text {th }}$ ed., Ingeborg SChwenzer, ed., Oxford University Press, Oxford, 2016).

Vogenauer, Stefan, Article 1.9, in Commentary on the Unidroit Principles of International Commercial Contracts (PICC), 192-201 (STEFAN VOGENAUER \& JAN Kleinheisterkamp, eds., Oxford University Press, Oxford, 2009).

\section{Journals}

Campuzano-Díaz, Beatriz, El Convenio de Viena de 11 de abril de 1980 como núcleo en la regulación de la compraventa internacional de mercaderías (comentario a propósito de la Sentencia arbitral de la CCI $n^{o}$. 8611/HVIJK de 23 de enero de 1997), 9 Derecho de los Negocios, 99, 15-28 (1998).

Castro y Bravo, Federico de, Las leyes nacionales, la autonomía de la voluntad y los usos en el proyecto de ley uniforme sobre la venta, XI Anuario de Derecho Civil, 4, 10031040 (1958). Available at: https://www.boe.es/publicaciones/anuarios_derecho/ abrir_pdf.php?id=ANU-C-1958-40100301040_ANUARIO_DE_DERECHO_ CIVIL_Las_leyes_nacionales,_la_autonom\%EDa_de_la_voluntad_y_los_ usos_en_el_proyecto_de_Ley_Uniforme_sobre_la_venta

Ferrari, Franco, The Relationship between International Uniform Contract Law 
Conventions, 22 Journal of Law and Commerce, $57-75$ (2003). Available at: https:// www.cisg.law.pace.edu/cisg/biblio/ferrari7.html

Ferrari, Franco, Trade Usage and Practices Established between the Parties under the CISG, 5 International Business Law Journal, 571-580 (2003).

FerRari, Franco, What Sources of Law for Contracts for the International Sale of Goods? Why One Has to Look Beyond the CISG, Internationales Handelsrecht, 1, 1-20 (2006). Available at: http://its.law.nyu.edu/faculty/profiles/representiveFiles/ What $\% 20$ sources $\% 20$ of $\% 201$ law $\% 20$ for $\% 20$ contracts_79455A8D-1B21-620660B362AD9AB7EC8D.pdf

Jokela, Heik ki, The Role of Usages in the Uniform Law on International Sales, 10 Scandinavian Studies in Law, 81-96 (1966). Available at: http://www.cisg.law. pace.edu/cisg/biblio/Jokela.html

Oviedo-Albán, Jorge, El carácter internacional y la interpretación uniforme de la Convención de Naciones Unidas sobre Compraventa Internacional de Mercaderías, XLV Boletín Mexicano de Derecho Comparado, 133, 253-282 (2012). Available at: http://www.scielo.org.mx/pdf/bmdc/v45n133/v45n133a9.pdf

Oviedo-Albán, Jorge, Los principios generales en la Convención de Naciones Unidas sobre Compraventa Internacional de Mercaderías, XLVII Boletín Mexicano de Derecho Comparado, 141, 987-1020 (2014). Available at: http://www.elsevier.es/ es-revista-boletin-mexicano-derecho-comparado-77-articulo-los-principiosgenerales-convencion-naciones-S0041863314711822

\section{International treaties and other legal sources}

Unidroit, International Institute for the Unification of Private Law, Unidroit Principles of International Commercial Contracts 2010 (Rome, 2010). Available at: http://www.unidroit.org/english/principles/contracts/principles2010/ integralversionprinciples2010-e.pdf

United Nations. Convention for International Sales of Goods. Available at: http://www. uncitral.org/pdf/english/texts/sales/cisg/V1056997-CISG-e-book.pdf

\section{Cases}

Argentina, National Commercial Court of First Instance No. 10, October $23^{\text {rd }} 1991$, Águila Refractarios S.C. s/ Conc. Preventivo. Available at: http://www.unilex.info

Argentina, National Commercial Court of First Instance, No. 10, October $6^{\text {th }} 1994$, Bermatex v. Valentin Rius. Available at: http://cisgw3.law.pace.edu/cases/941006a1. html

Austria, Oberlandesgericht Graz, November $9^{\text {th }} 1995$, CLOUT No. 175. Available at: http://cisgw3.law.pace.edu/cases/951109a3.html

Austria, Oberster Gerichtshof, February $2^{\text {nd }} 1995$, CLOUT No. 176. Available at: http:// cisgw3.law.pace.edu/cases/960206a3.html

Austria, Oberster Gerichtshof, October $15^{\text {th }}$ de 1998, CLOUT No. 240. Available at: 
http://cisgw3.law.pace.edu/cases/981015a3.html

Austria, Oberster Gerichtshof, 10 Ob 344/99g, March 21 $1^{\text {st }}$ 2000, CLOUT No. 425. Available at: http://cisgw3.law.pace.edu/cases/000321a3.html

Germany, Amtsgericht, April $13^{\text {th }}$ 2000, CLOUT No. 360. Available at: http://cisgw3. law.pace.edu/cases/000413g1.html

Germany, Oberlandesgericht Frankfurt, July $5^{\text {th }} 1995$, CLOUT No. 276. Available at: http://cisgw3.law.pace.edu/cases/950705g1.html

ICC, Court of Arbitration of the International Chamber of Commerce, ICC Arbitration Case 8611/HV/JK, January 23 ${ }^{\text {rd }} 1997$. Available at: http://cisgw3.law.pace.edu/ cases/978611il.html

ICC, Tribunal of International Commercial Arbitration at the Russian Federation Chamber of Commerce and Industry, ICC Arbitration Case 229/1996, June $5^{\text {th }}$ 1997. Available at: http://cisgw3.law.pace.edu/cases/970605r1.html

ICC, Court of Arbitration of the International Chamber of Commerce, ICC Arbitration Case, 9333, 1998. Available at: http://cisgw3.law.pace.edu/cases/989333i1.html

Switzerland, Zivilgericht Kanton Basel-Stadt, December 21st 1992, CLOUT No. 95. Available at: http://cisgw3.law.pace.edu/cases/921221s1.html

United States, U.S. Court of Appeals (5th Circuit) [Federal Appellate Court], June 11th 2003, BP Oil International, Ltd., and BP Exploration \& Oil, Inc., v. Empresa Estatal de Petróleos de Ecuador et al., CCA (5th Circuit), [02-20166]. Available at: http://cisgw3.law.pace.edu/cases/030611u1.html

United States, U.S. District Court for the Southern District of New York [Federal Court of 1st instance], March $26^{\text {th }}$ 2002, St. Paul Guardian Insurance Company et al. v. Neuromed Medical Systems \& Support et al. DC (Southern Dist., NY) [00 Civ. 934 (SHS)]. Available at: http://cisgw3.law.pace.edu/cases/020326u1.html

United States, U.S. District Court for the Southern District of New York [Federal Court of 1st instance], May 10 ${ }^{\text {th }}$ 2002, Geneva Pharmaceuticals Tech. Corp. v. Barr Labs. Inc. [98 CIV 861 (RWS) and 99 Civ 3607 (RWS)] DC (Southern Dist. NY). Available at: http://cisgw3.law.pace.edu/cases/020510u1.html

\section{Another documents}

Legislative History. 1980 Vienna Diplomatic Conference G. Report of the First Committee [Outline of Committee Proceedings] Document A/CONF.97/11 [Original: English 7th April 1980]. Available at: http://www.cisg.law.pace.edu/cisg/1stcommittee/ summaries10.html 